\title{
Relações vivas e acerto de contas
}

\author{
Maria Helena Serôdio
}

Este número - que inaugura o quinto ano da publicação da nossa revista - vem comprovar como o território do teatro é, afinal, um feixe de múltiplas relações vivas, na medida em que não se limita ao lugar do palco, antes se prolonga - ou antecipa - em muitas outras circunstâncias que modalizam a sua presença e a tornam rizomática. Disso mesmo é prova a amplitude das realidades que o júri da Associação Portuguesa de Críticos de Teatro distinguiu este ano e que o Dossiê temático explicita: por um lado, contemplando uma actriz de carreira bem firmada como é Emília Silvestre, uma editora como a Cotovia (que tem publicada uma colecção apreciável de textos de teatro) e um projecto - Palcos novos / Palavras novas (PANOS) - que envolve escolas do ensino secundário; e, por outro lado, "repartindo" o Prémio entre um espectáculo sobre um texto canónico de uma companhia de longo e excelente fôlego artístico, como é o Teatro da Cornucópia, e uma outra bem mais recente - Primeiros Sintomas - que se afoitava por uma dramaturgia contemporânea de choque. Sinais, portanto, de caminhos cruzados que enriquecem o tecido cultural que o teatro inventa e a que a APCT quer estar atenta.

Pelo seu lado, também a academia vem permanentemente activando a análise, a discussão e o interesse por autores dramáticos e pelo teatro em geral através de publicações, conferências, teses ou programas de seminários e cadeiras, estabelecendo diálogos e criando vínculos que se posicionam antes e depois da realidade espectáculo. É o caso aqui, por exemplo, dos autores dramáticos que ocupam o Portefólio que Paulo Eduardo Carvalho apresenta e que corresponde a uma sequência que estudou em profundidade para a sua tese de doutoramento, bem como o texto, que ocupa o Arquivo solto, que decorre da tese de mestrado em Estudos de Teatro que Paula Magalhães apresentou à Faculdade de Letras da Universidade de Lisboa.

Se as Notícias de fora nos transportam de Nova lorque a Sheffield e a Tessalonica para nos falarem de realidades já consagradas, os Estudos aplicados - que decorrem de um colóquio organizado pelo Centro de Estudos de Teatro da Universidade de Lisboa - centram-se em Harold Pinter propondo uma revisitação histórica e teórica à sua dramaturgia ancorada em três pontos geográficos bem distantes: Estados Unidos da América, Inglaterra e Brasil. Entretanto, os Passos em volta procuram trazer à discussão espectáculos que terão passado mais despercebidos à imprensa, revelando actuações sobretudo fora de Lisboa que comprovam a vitalidade de várias companhias que se distribuem por outros circuitos que não os mais engalanados ou de maior visibilidade.

Na entrevista a João Perry, ouvido Na primeira pessoa, sobressai o fulgor - contido e exigente - de um actor com uma carreira celebrada a falar do seu trajecto de vida e dos valores que defende na sua actuação, enquanto o $\mathrm{Em}$ rede, de Ana Bigotte Vieira, nos fala de novos rumos de uma cultura digital não apenas a reorganizar a arte, mas também a ditar comportamentos na vida. E é ainda em torno do cruzamento da vida com a arte, bem como do teatro com a literatura, a fotografia e o registo ou criação videográfica que as Leituras se tecem, não faltando como é já norma do n. ${ }^{\circ}$ de Junho - a lista de publicações que Sebastiana Fadda vem alinhando de forma exaustiva.

Mas neste looping de relações acesas a verdade é que regressamos sempre ao ponto incandescente que é o espectáculo: o que é, quem o faz e quem, ao vê-lo (ou ao fotografá-(o), também o - e se - vai fazendo. A eles ficamos a dever tudo isso, bem como o apoio generoso que nos vão prodigalizando com cedência de fotografias, esclarecimento de dúvidas e uma sempre amável solicitude que muito nos anima.

Por isso também nos move a vontade de corrigir o que por vezes desacertamos, pelo que aqui incluimos um "acerto de contas" para o qual escolhemos uma epígrafe da nossa maior afeição:

Es irrt der Mensh, so lang' er strebt (Erra o homem enquanto se esforça e procura) (Goethe, Faust, "Prolog im Himmel", v. 317) 


\section{Onde se lê:}

N. ${ }^{\circ}$ 3, Junho de 2005

p. 111

legenda da imagem

N. ${ }^{\circ}$ 5, Junho de 2006

p. 40

Beckett em Portugal: Uma cronologia

(col. da esq.)

N. ${ }^{\circ}$ 6, Dezembro de 2006

p. 35

Rogério de Carvalho - Representações singulares (col. da esq. ao fundo):

N. ${ }^{\circ}$ 7, Junho de 2007

p. 76

Prémios de teatro regressam à Grécia

(col. da esquerda, última linha):

N. ${ }^{\circ}$ 8, Dezembro de 2007

p. 39

Cronologia teatral de Fiama Hasse Pais

Brandão

p. 40

Cronologia teatral de Fiama ... (cont.)

\section{Ramada Curto} Trafaria. (desenho de Roberto Nobre)

\section{Quatro em Beckett ...}

\section{À espera de Godot..}

... Grupo de Intervenção Teatral da

... terem decorrido em Milão.

1970: É-Ihe atribuido o Prémio da Secretaria de Estado da Cultura para Quem move as árvores (Lisboa, 1979).

1976: ... Em Portugal a autora recusa o Prémio... (desenho de Amarelhe)

Deve ler-se:

Quatro em Beckett ...

Um dia virá [Inominável, Acto sem palavras, Á espera de Godot], enc. Mónica Calle, Prod. Casa Conveniente/CCB

À espera de Godot...

Grupo de Intervenção Teatral da Trafaria, onde se estreou na encenação de Tchekov em 1977 com Três irmãs que, a convite da Cornucópia, se apresentou no Teatro do Bairro Alto em Janeiro de 1978.

... terem decorrido em Turim.

1970: É-Ihe atribuído o Prémio de Teatro Maria Matos pela peça Quem move as árvores (Lisboa, 1979). Este prémio era organizado em colaboração com a Sociedade de Escritores e Compositores Teatrais Portugueses (SEC TP)

[Informação da autora que não foi possivel confirmar] 